\title{
AMP-activated protein kinase can induce apoptosis of insulin-producing MIN6 cells through stimulation of c-Jun-N-terminal kinase
}

\author{
B A Kefas, Y Cai, Z Ling, H Heimberg, L Hue ${ }^{1}$, D Pipeleers and \\ M Van de Casteele
}

Diabetes Research Centre, Brussels Free University-VUB, Brussels, Belgium

${ }^{1}$ Hormone and Metabolic Research Unit, University of Louvain Medical School and Christian de Duve International Institute of Molecular and Cellular Pathology, Brussels, Belgium

(Requests for offprints should be addressed to M Van de Casteele, Diabetes Research Centre, Free Brussels University-VUB, Laarbeeklaan, 103, B-1090 Brussels, Belgium; Email: mvdcaste@vub.ac.be)

\begin{abstract}
We have recently shown that conditions known to activate AMP-activated protein kinase (AMPK) in primary $\beta$-cells can trigger their apoptosis. The present study demonstrates that this is also the case in the MIN6 $\beta$-cell line, which was used to investigate the underlying mechanism. Sustained activation of AMPK was induced by culture with the adenosine analogue AICA-riboside or at low glucose concentrations. Both conditions induced a sequential activation of AMPK, c-Jun-N-terminal kinase (JNK) and caspase-3. The effects of AMPK on JNK activation and apoptosis were demonstrated by adenoviral expression of constitutively active AMPK, a condition which reproduced the earlier-described AMPK-dependent effects on pyruvate kinase and acetyl-coA-carboxylase. The effects of JNK activation on apoptosis were demonstrated by the observations that (i) its inhibition by dicumarol prevented caspase- 3 activation and apoptosis, (ii) adenoviral expression of the JNK-interacting scaffold protein JIP-1/IB-1 increased AICA-riboside-induced JNK activation and apoptosis. In primary $\beta$-cells, AMPK activation was also found to activate JNK, involving primarily the JNK 2 (p54) isoform. It is concluded that prolonged stimulation of AMPK can induce apoptosis of insulin-producing cells through an activation pathway that involves JNK, and subsequently, caspase-3.
\end{abstract}

Journal of Molecular Endocrinology (2003) 30, 151-161

\section{Introduction}

The AMP-activated protein kinase (AMPK) is a serine/threonine protein kinase that is composed of a catalytic subunit $(\alpha)$ and two regulatory subunits ( $\beta$ and $\gamma$ ) (Davies et al. 1994, Hardie et al. 1998). In various cell types, AMPK has been described as a sensor for the energy state, serving as a metabolic master switch (Hardie \& Carling 1997, Hardie et al. 1998, Winder \& Hardie 1999). Any increase in the intracellular AMP/ATP ratio activates AMPK (Hardie \& Carling 1997, Hardie et al. 1998, Winder \& Hardie 1999). AMPK activation can thus occur under environmental stress, such as high fructose concentrations in liver, heat shock, exercise and electrical stimulation in skeletal muscle, and ischaemia in heart (Moore et al. 1991, Corton et al.
1994, Winder \& Hardie 1999, Marsin et al. 2000, Musi et al. 2001). AMPK can also be activated by an adenosine analogue, 5-aminoimidazole-4carboxamide (AICA)-riboside, following its phosphorylation to AICA-ribotide (also called ZMP), which is an analogue of AMP (Sabina et al. 1985). This effect of AICA-riboside has been observed in liver cells, pancreatic $\beta$-cell lines and, to a certain extent, skeletal muscle (Sullivan et al. 1994, Corton et al. 1995, Salt et al. 1998, Da Silva et al. 2000).

In certain cell types, the AMP/ATP ratio, and hence AMPK activity, strongly depends on the supply and utilisation of substrates, such as glucose. This was the case in $\beta$-cell lines that were cultured in low glucose (Salt et al. 1998, Da Silva et al. 2000). Their AMPK activation has been considered responsible for an inhibition of insulin release (Salt 
et al. 1998) and for a transcriptional regulation of glucose-responsive genes (Da Silva et al. 2000). However, in primary $\beta$-cells, an activation of AMPK can cause apoptosis (Kefas et al. 2003), which might explain the earlier reported induction of programmed cell death in rat $\beta$-cells that had been cultured at low glucose concentrations (Hoorens et al. 1996). In the present study, we found that this is also the case in mouse insulinoma MIN6 cells which had been cultured at low glucose concentrations or in the presence of AICA-riboside. This observation allowed us to use the cell line to examine further the mechanism through which AMPK can induce apoptosis.

\section{Materials and methods}

\section{Cell culture and adenoviral infection}

Rat pancreatic $\beta$-cells were isolated and cultured as previously described (Hoorens et al. 1996). Mouse pancreatic $\beta$-cell-derived MIN6 cells (passages 20-30) were cultured in DMEM with 15\% fetal bovine serum in 0.6 or $25 \mathrm{mM}$ glucose (Van de Casteele et al. 2002). AICA-riboside and/or dicumarol (Sigma) was added to the incubation medium as indicated. The general caspase inhibitor z-Val-Ala-Asp-fluoromethylketone (z-VAD-fmk) (Bachem, Babendorf, Switzerland) was added to cell cultures at a concentration of $100 \mu \mathrm{M}, 1 \mathrm{~h}$ before transferring the cells to apoptogenic culture conditions.

MIN6 cells were infected at $100 \mathrm{pfu} /$ cell with an adenovirus (Ad.GFP/ $\alpha 1^{312}$ ) expressing both a Myctagged constitutively active form of AMPK (protein $\alpha 1^{312}$ ) and the green fluorescent protein (GFP), or with a control adenovirus (Ad.GFP) expressing only GFP. In other experiments, MIN6 cells were infected at 25 or $50 \mathrm{pfu} / \mathrm{cell}$ with an adenovirus (Ad.IB-1) expressing the scaffold protein JIP-1/IB-1 (but not GFP), or with a control adenovirus (Ad.Luc) expressing luciferase. Viral infection was carried out as previously described (Woods et al. 2000). Ad.IB-1 virus was kindly provided by Dr G Waeber (Department of Internal Medicine, University Hospital, Lausanne, Switzerland).

\section{Detection and quantification of apoptosis}

Living, apoptotic and necrotic cells were detected and quantified by fluorescence microscopy using propidium iodide (PI) (Sigma, St Louis, MO, USA) and Hoechst 3342 (Sigma) (Hoorens et al. 1996). The majority of apoptotic cells that accumulate during culture are microscopically recognised through their fragmented nuclei that fluoresce for both compounds; cells were photographed as described (Hoorens et al. 1996). Apoptotic cells containing sub-G1 (apoptotic) nuclei were also identified and counted by fluorescence-activated cell sorting (FACS) analysis (Nicoletti et al. 1991, Van de Casteele et al. 2002).

Oligonucleosomal DNA fragmentation in MIN6 cells was detected by gel electrophoresis. Following culture, adherent and floating cells were separated, their DNA was extracted by the salting-out procedure (Miller et al. 1988) and then precipitated with ethanol, air-dried and dissolved in sterile water. After extraction, DNA was treated with RNAse, and subjected to electrophoresis on $1 \%$ agarose gels containing ethidium bromide.

\section{Assay of caspase-3 activity in cell extracts}

Cells were lysed in a $10 \mathrm{mM}$ Hepes buffer $(\mathrm{pH} 7 \cdot 4)$ containing $0 \cdot 1 \%$ 3-[(3-cholamidopropyl)-dimethylammonio]-1-propane-sulfonate, $10 \mathrm{mM}$ dithiothreitol, $2 \mathrm{mM}$ EDTA, $1 \mathrm{mM}$ phenylmethanesulphonyl fluoride, $10 \mu \mathrm{g} / \mathrm{ml}$ leupeptin, $10 \mu \mathrm{g} / \mathrm{ml}$ aprotinin and $20 \mu \mathrm{g} / \mathrm{ml}$ pepstatin. Samples $(25-50 \mu \mathrm{g}$ protein) were incubated with $50 \mu \mathrm{M}$ N-acetyl-Asp-Glu-ValAsp-7-amino-4-methylcoumarin for $3 \mathrm{~h}$ at room temperature. The AMC cleavage product was detected fluorimetrically at $460 \mathrm{~nm}$ (excitation at $360 \mathrm{~nm}$ ). Caspase-3 specific activity is expressed as fluorescence units per $\mathrm{mg}$ protein and per min. Caspase- 3 activity was also expressed relative to the activity measured in untreated cells.

\section{Pyruvate kinase mRNA expression}

Polyadenylated RNA was isolated from MIN6 cells and reverse transcribed as previously detailed (Van de Casteele et al. 2002). PCR was performed on the cDNA using specific primers for L-type pyruvate kinase and $\beta$-actin (Da Silva et al. 2000).

\section{Western blotting}

Cells were detached by brief incubation at $37{ }^{\circ} \mathrm{C}$ in PBS containing $1 \mathrm{mM}$ EDTA and $1 \%$ BSA. 
After two washes, the harvest was lysed by $30-\mathrm{s}$ sonication in RIPA buffer containing protease and phosphatase inhibitors (Heimberg et al. 2000), and then cleared by centrifugation $(12000 \boldsymbol{g}, 5 \mathrm{~min})$. Protein concentration was measured by the Micro BCA assay (Pierce, Rockford, IL, USA) using BSA as a standard. Under reducing conditions, proteins were resolved by standard 12-15\% SDS-PAGE, and transferred to nitrocellulose membranes (Schleicher \& Schuell, Dassel, Germany). Membranes were blocked and incubated in 5\% non-fat milk (w/v) in TBS/Tween $(10 \mathrm{mM}$ Tris-HCl pH 7.5, $150 \mathrm{mM} \mathrm{NaCl}, 0.05 \%$ (v/v) Tween-20). Monoclonal IgGl antibodies directed against phospho-(Ser63)-c-Jun (Santa Cruz Biotechnology, Santa Cruz, CA, USA) or C-terminal human c-Myc (clone 9E10.3; Biosource, Camanillo, CA, USA), and polyclonal antibodies against phospho-(Thr183/Tyr185)-c-Jun-N-terminal kinase (JNK) 1/2, total JNK (New England Biolabs, Beverly, MA, USA), phospho-(Ser79)-acetyl-coAcarboxylase (Upstate, Lake Placid, NY, USA), JIP-1/IB-1 (gift of Dr G Waeber, Department of Internal Medicine, University Hospital, Lausanne, Switzerland), GFP (Promega, Madison, WI, USA) or actin (Santa Cruz Biotechnology), were added at 1:400-1:1000 dilution, and the membranes incubated overnight with shaking at $4{ }^{\circ} \mathrm{C}$. They were then washed three times for $15 \mathrm{~min}$ in TBS/ Tween, and incubated with anti-rabbit IgG horseradish peroxidase (HRP)-linked whole antibody from donkey or with anti-mouse IgG HRP-linked antibody from sheep (Amersham) for $50 \mathrm{~min}$. Proteins were revealed using the enhanced chemiluminescence reaction (Amersham, Piscataway, NJ, USA).

\section{Protein kinase assays}

\section{AMPK activity}

Cells $\left(5-8 \times 10^{6}\right)$ were lysed in $800 \mu$ ice-cold lysis buffer (Marsin et al. 2000). Total AMPK activity was assayed after precipitation with $10 \%(\mathrm{w} / \mathrm{v})$ polyethylene glycol 6000. AMPK activity was measured by phosphorylation of the synthetic peptide SAMS (HMRSAMSGLHLVKRR) in the presence of $0.2 \mathrm{mM}$ AMP (Marsin et al. 2000). One unit of AMPK activity corresponds to 1 pmol of phosphate incorporated per min under the selected assay conditions.

\section{JNK activation}

MIN6 cells were lysed in the same buffer as for AMPK activity measurements (Marsin et al. 2000). Phosphorylation of JNK $1 / 2$ on specific Thr and Tyr residues, and of c-Jun on specific Ser residues was detected by Western blotting.

\section{Statistical analysis of data}

Data are expressed as means \pm S.E.M. of at least three independent experiments. Statistical significance of differences with the mean are calculated by Student's two-way $t$-test for paired data or by ANOVA with the Scheffe F-test for multiple comparisons.

\section{Results}

\section{AICA-riboside induced caspase-3 activation and apoptosis in MIN6 cells}

Similar to its effects in primary rat $\beta$-cells, AICAriboside induced apoptosis in subconfluent cultures of the MIN6 $\beta$-cell line. Apoptotic cells were easily recognised by a fluorescence assay following $24 \mathrm{~h}$ culture with AICA-riboside (Fig. 1A). They detached from the culture dish so that their identity could be confirmed by analysis of the floating material. Thus, this fraction was characterised by oligonucleosomal DNA laddering that did not appear in the presence of the caspase inhibitor zVAD-fmk (Fig. 1B). Between 0.5 and $2 \mathrm{mM}$ AICA-riboside, FACS analysis indicated a dose-dependent appearance of apoptotic cells, as identified by their sub-G1 DNA content (Fig. 1C). DNA degradation induced by $2 \mathrm{mM}$ AICAriboside was completely prevented by addition of zVAD-fmk (Fig. 1C). At 2 mM AICA-riboside, a time-dependent rise in caspase-3 activity was measured between 12 and $36 \mathrm{~h}$ of culture (Fig. 1D). At low glucose $(0.6 \mathrm{mM})$, caspase activity was slightly increased after $12 \mathrm{~h}$, and further raised during the following $36 \mathrm{~h}$ up to 8-fold higher values than in control cells cultured at $25 \mathrm{mM}$ glucose (Fig. 1D).

\section{AICA-riboside-induced AMPK activation and JNK activation followed by caspase-3 activation}

When MIN6 cells were cultured with $2 \mathrm{mM}$ AICA-riboside, they rapidly exhibited an elevation in their AMPK activity, starting after 15 min and 
A

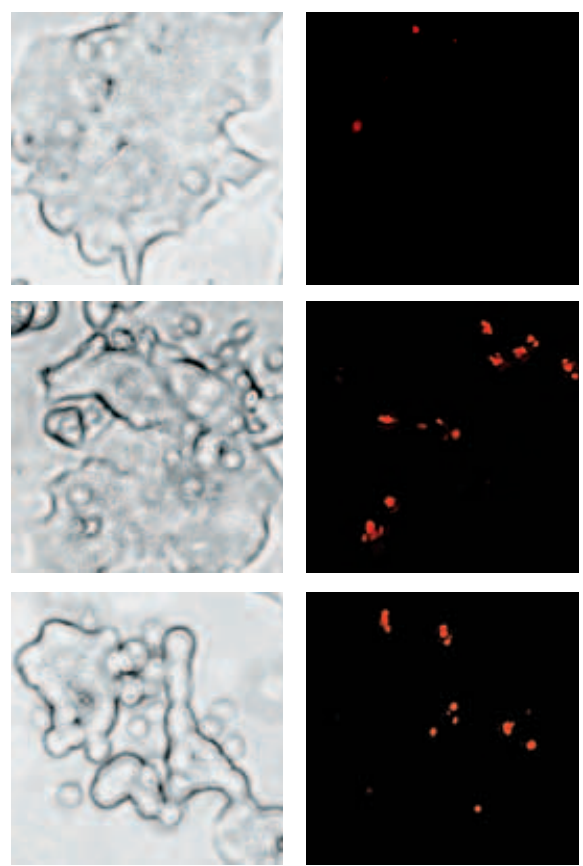

B
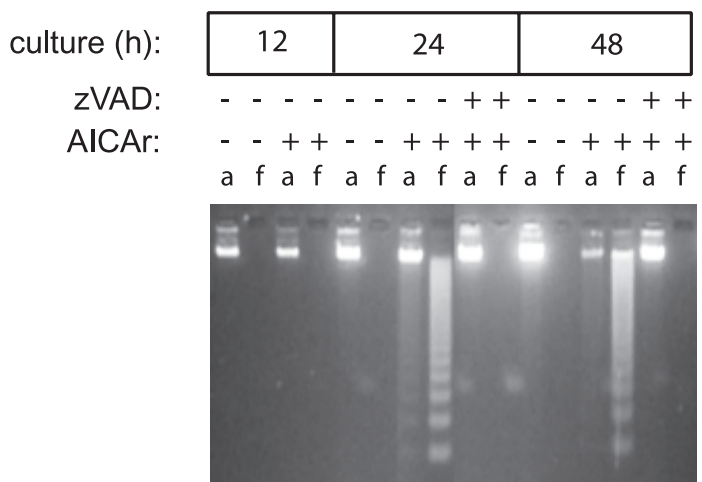

C

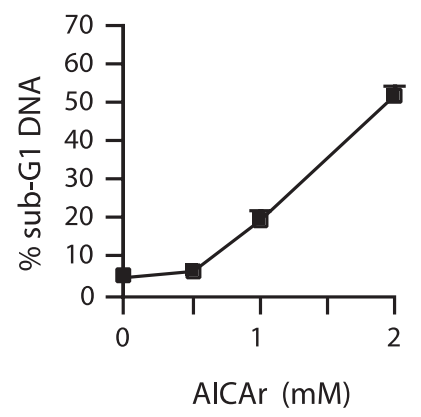

AICAr
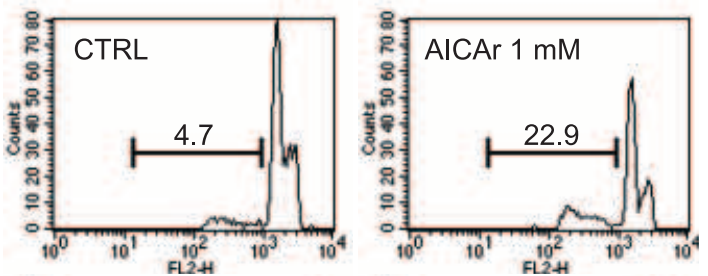

LG
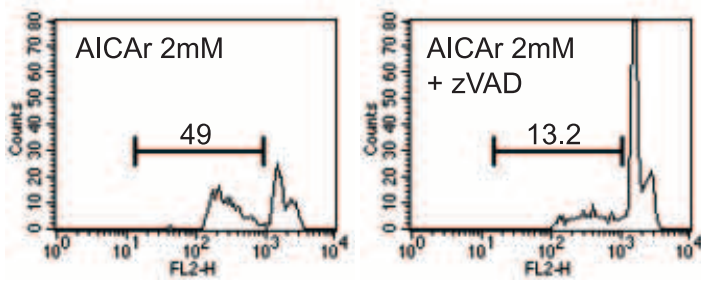

D

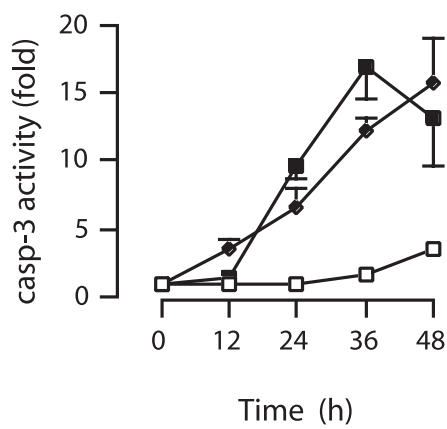

Figure 1 AICA-riboside and low glucose concentration induce caspase- 3 activation and apoptosis in the $\beta$-cell line MIN6. (A) Phase contrast (left) and PI fluorescence (right) microscopy of MIN6 cells following culture for $24 \mathrm{~h}$ in the absence (CTRL) or presence of $2 \mathrm{mM} \mathrm{AICA-riboside} \mathrm{(AICAr)} \mathrm{or} \mathrm{at} \mathrm{a} \mathrm{glucose} \mathrm{concentration} \mathrm{of} 0.6 \mathrm{mM}(\mathrm{LG})$. AICAr and low glucose increase the number of isolated rounded-up cells (left) with PI-positive nuclear fragments or pyknotic nuclei (right). The micrographs are representative of three to five experiments. (B) MIN6 cells were cultured in the absence (-) or in the presence (+) of 2 mM AICA-riboside (AICAr), without (-) or with (+) $100 \mu \mathrm{M} \mathrm{z-VAD-fmk} \mathrm{(zVAD),}$ for the indicated periods of time. DNA of attached (a) and floating (f) MIN6 cells was extracted and analysed on agarose gel as described in the Methods section. The results shown are representative of three experiments. (C) For quantifying apoptosis in the MIN6 cell line, subconfluent cultures were exposed to the indicated concentrations of AICA-riboside (AICAr) for $36 \mathrm{~h}$. The percentage of the cells that displayed sub-G1 quantities of DNA was measured as described in Methods, and was plotted as the mean \pm S.E.M. of six experiments (upper panel). FACS histograms are representative of six experiments (lower panels); the numbers indicate the percentage of cells that appeared in the sub-G1 gate (defined by horizontal lines). The DNA degradation induced by $2 \mathrm{mM}$ AlCAr was inhibited by $100 \mu \mathrm{M}$ zVAD-fmk (zVAD). (D) MIN6 cells were cultured for the indicated periods of time in the absence ( $\square$ ) or in the presence of $2 \mathrm{mM}$ AICA-riboside $(\boldsymbol{\square})$, or at the glucose concentration of $0.6 \mathrm{mM}$ glucose ( $)$. Caspase-3 activity was measured as described in Methods. The values shown are the means \pm S.E.M. of five independent experiments. 
reaching, after $1 \mathrm{~h}$, a plateau that was maintained for $12 \mathrm{~h}$ (Fig. 2A). The AMPK activation was accompanied by an activation of JNK which became detectable within $1 \mathrm{~h}$ and was persistent for up to $24 \mathrm{~h}$ (Fig. 2B). In addition, AMPK activation was also associated with JNK activation in primary $\beta$-cells (Fig. 2C). Both activation processes preceded that of caspase-3 (Fig. 1D; Kefas et al. 2003). In primary $\beta$-cells, increased JNK phosphorylation was noted to occur primarily on the JNK 2 (p54) isoform (Fig. 2C).

A

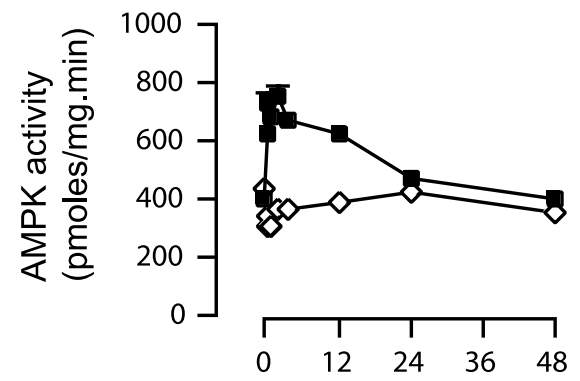

Time (h)

B

Time (h) $\quad \begin{array}{lllllllll}0 & 1 / 4 & 1 / 2 & 1 & 2 & 4 & 12 & 24 & 48\end{array}$

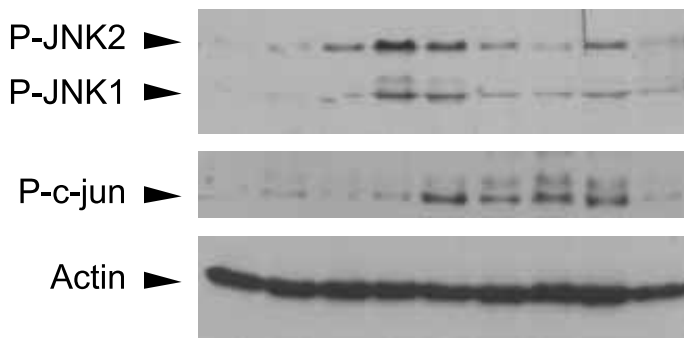

C

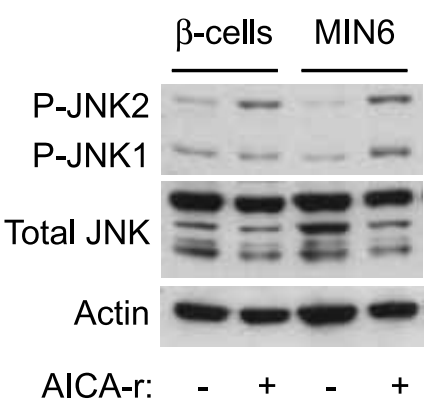

\section{AMPK stimulated JNK in MIN6 cells}

To investigate whether AMPK could be responsible for the JNK activation, MIN6 cells were infected with an adenovirus (Ad.GFP/ $\alpha 1^{312}$ ) that encodes GFP as well as a truncated $\alpha 1$-AMPK catalytic subunit which is c-Myc tagged and which bears a Thr-172-Asp mutation in the activation loop. The mutated $\alpha 1^{312}$ protein acts as a constitutively active form of AMPK (Woods et al. 2000). MIN6 cells infected with either Ad.GFP/ $\alpha 1^{312}$ or Ad.GFP were analysed for the expression of GFP and the mutant protein $\alpha 1^{312}$, as well as for AMPK activity, activation of endogenous JNK, and DNA fragmentation. Compared with the Ad.GFP infected cells, the Ad.GFP/ $\alpha 1^{312}$-infected cells expressed an elevated AMPK activity (Fig. 3A). Expression of the constitutively active mutant of AMPK resulted in activation of endogenous JNK (Fig. 3B), and caused DNA degradation (Fig. 3A). This indicated that activation of AMPK entails JNK activation and apoptosis in MIN6 cells. Besides these effects, expression of constitutively active AMPK also resulted in a reduced expression of L-type pyruvate kinase mRNA (Fig. 3G) as well as an increased phosphorylation of acetyl-coAcarboxylase in MIN6 cells (Fig. 3D), showing that expression of the recombinant AMPK reproduced known regulatory effects of AMPK activation (Hardie \& Carling 1997, Hardie et al. 1998, Da Silva et al. 2000).

Figure 2 Activation of AMPK and JNK by AICA-riboside. (A) MIN6 cells were cultured for the indicated periods of time without $(\diamond)$ or with $2 \mathrm{mM} \mathrm{AICA}$-riboside $(\square)$. AMPK specific activity was determined as detailed in the Methods section. The values shown are the means \pm S.E.M. of four to eight experiments. (B) Phosphorylation of JNK (P-JNK1 and 2) and C-Jun (P-C-jun) was assessed in MIN6 cells cultured for the indicated periods of time in the presence of $2 \mathrm{mM}$ AICA-riboside by Western blot analysis using anti-phospho-specific antibodies. Actin was detected to assess protein loading. Results shown are representative of three experiments. (C) Purified rat $\beta$-cells and MIN6 cells were cultured in the absence or presence of $2 \mathrm{mM}$ AICA-riboside (AICA-r) for $10 \mathrm{~h}$, after which their JNK activation was examined by Western blotting. Fifteen micrograms of total proteins from either $\beta$-cells or MIN6 cells were loaded per lane, and phospho-JNK (1/2), total JNK and actin were detected by immunoblotting. AICA-riboside induced predominantly a phosphorylation of JNK 2 (54 kDa isoform) in primary $\beta$-cells. Results shown are representative for three independent experiments. 
A

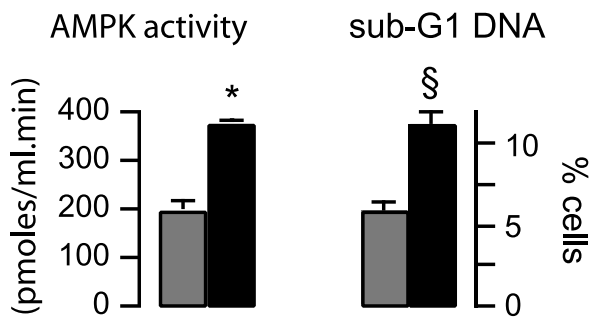

B

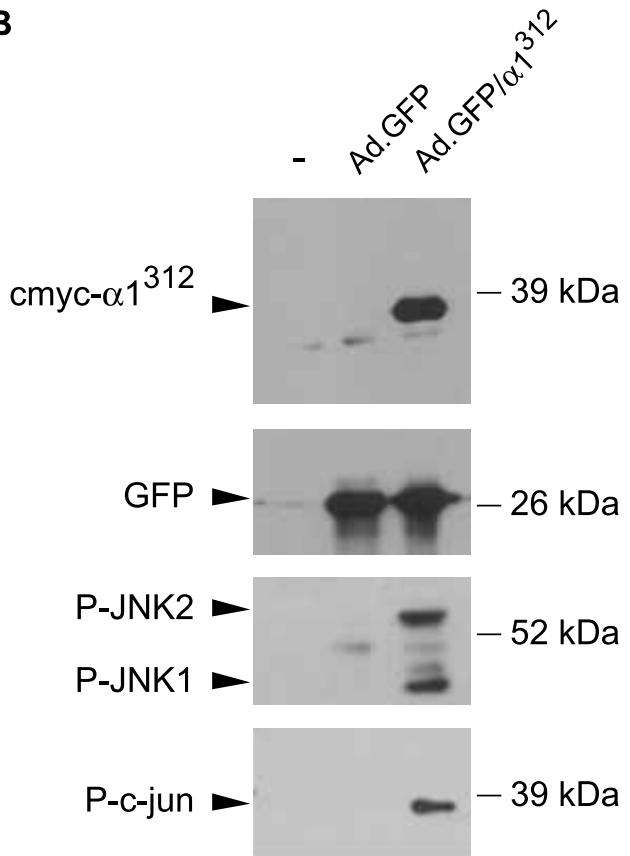

C

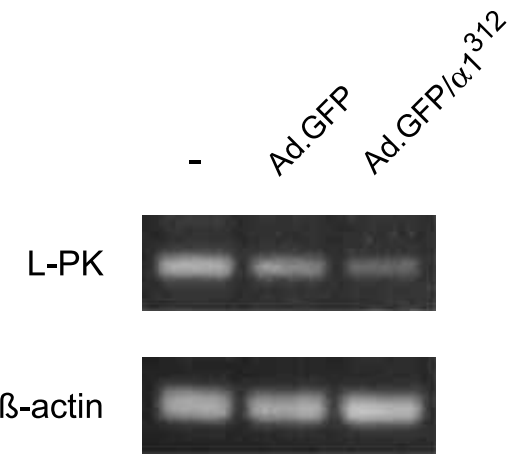

D

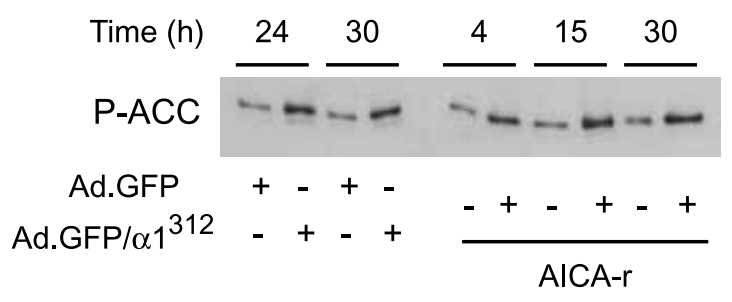

Figure 3 Expression of constitutively active AMPK leads to JNK activation in MIN6 cells. MIN6 cells were infected with either adenovirus expressing only GFP (Ad.GFP) or adenovirus expressing also constitutively active AMPK (Ad.GFP/ $/ 1^{312}$ ) at $100 \mathrm{pfu} / \mathrm{cell}$, or cells remained uninfected $(-)$. (A) The activity of AMPK (left) and the percentage of cells displaying sub-G1 DNA (right) were measured after $30 \mathrm{~h}$ of expression, in Ad.GFP and Ad.GFP/ $\alpha 1^{312}$. infected cells (grey and black bars respectively), as described in the Methods section. The FACS gate setting for detecting sub-G1 cells was identical to that used in Fig. 1C. The values shown are the means \pm S.E.M. of three or four experiments ( ${ }^{*} P<0.05$ and $\S P<0.01$ vs Ad.GFP). (B) After $30 \mathrm{~h}$ of viral expression cells were probed for recombinant AMPK (c-Myc tagged $\alpha 1^{312}$ ), GFP and phosphorylation of endogenous JNK (1/2) and c-Jun, by Western blotting. (C) Polyadenylated RNA was extracted from the cells after $30 \mathrm{~h}$ of viral expression and RT-PCR was performed to detect L-pyruvate kinase (L-PK) and $\beta$-actin mRNA. In Ad.GFP/ $\alpha 1^{312}$-infected cells the L-PK mRNA level was decreased as compared with Ad.GFP-infected or uninfected control cells. (D) Immunoblotting for phosphorylated acetyl-coA-carboxylase (P-ACC) in MIN6 cells after the indicated periods of viral expression (left), or in uninfected MIN6 cells cultured with or without $2 \mathrm{mM}$ AICA-riboside for the indicated times (right). Results shown in (B-D) are representative of three experiments each.

\section{JNK activation contributed to caspase-3 activation and apoptosis in MIN6 cells}

The respective kinetics of the measured activations (Figs 2 and 1D) are compatible with a temporal sequence from AMPK, over JNK to caspase-3. We next examined the causality of this sequence in AICA-riboside-induced apoptosis. The JNK inhibitor dicumarol has been demonstrated to inhibit 
A
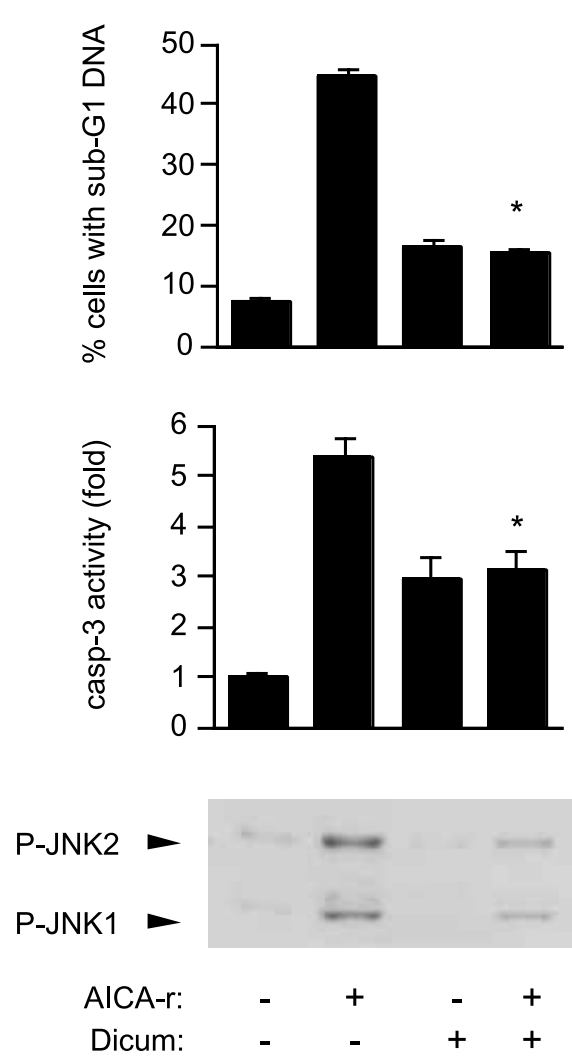

B
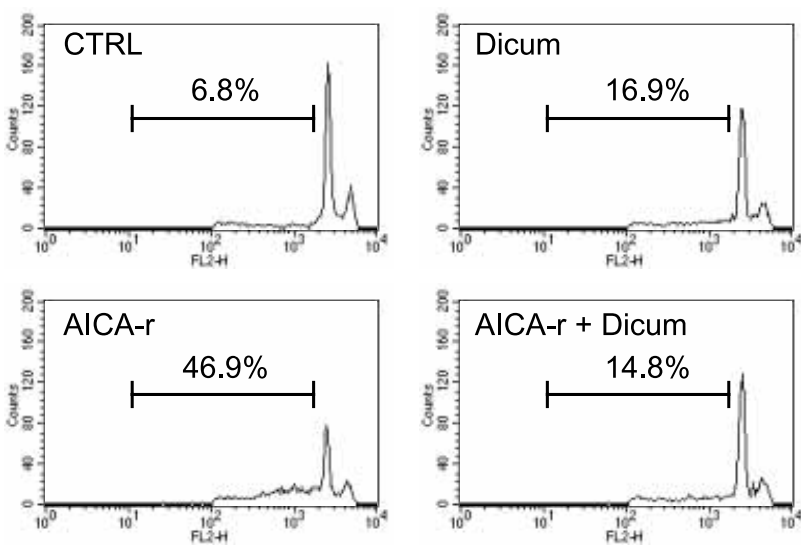

Figure 4 Dicumarol inhibits AICA-riboside-induced JNK activation, caspase-3 activation and DNA fragmentation in MIN6 cells. (A) The effects of $100 \mu \mathrm{M}$ of the JNK inhibitor dicumarol (Dicum) on the activations of JNK and caspase-3 induced by $5 \mathrm{mM}$ AICA-riboside (AICA-r) were assessed in MIN6 cells treated for 4 and $24 \mathrm{~h}$ respectively. Caspase-3 activity was measured as in Fig. 1D, and expressed relative to the activity in untreated cells. The values shown are the means \pm S.E.M. of five experiments. JNK phosphorylation was detected as in Fig. 2B. Effects of dicumarol on the DNA degradation induced by AICA-riboside were evaluated after $24 \mathrm{~h}$. The percentage of cells with a sub-G1 DNA content was determined by FACS and data shown represent means \pm S.E.M. of four experiments ( ${ }^{*} P<0.01$ vs AICA-r by ANOVA). (B) Qualitative assessment of inhibition of DNA degradation by dicumarol. FACS histograms are representative for the data shown in (A). Percentage of cells with a sub-G1 DNA content is indicated above the horizontal bar representing the gate setting.

JNK activation in MCF-7 cells without affecting p38 MAPK, IкB, or Akt phosphorylation in these cells (Krause et al. 2001). When added to MIN6 cells, dicumarol was found to inhibit AICAriboside-induced activation of both JNK and caspase-3 (Fig. 4A). Dicumarol also inhibited DNA degradation induced by AICA-riboside (Fig. 4A and $\mathrm{B}$ ). These results suggest that JNK activation contributed to caspase- 3 activation and apoptosis.

The scaffold protein JIP-1/IB-1 is known to bind to JNK and its upstream kinases forming a transducing complex wherein JNK is activated in response to extracellular stimuli (Bonny et al. 2000).
We therefore examined the effect of JIP-1/IB 1 on AICA-riboside-induced JNK activation and apoptosis. This study was conducted in MIN6 cells that were infected with an adenovirus (Ad.IB-1) expressing JIP-1/IB-1 (Tawadros et al. 2002). These cells expressed higher levels of the JIP-1/IB-1 protein (Fig. 5A), and showed increased levels of JNK phosphorylation (Fig. 5A) and apoptosis (Fig. 5B) following AICA-riboside treatment; data were compared with non-infected controls and with cells infected with the luciferase-expressing adenovirus Ad-Luc. These results suggest that IB-1 expression facilitates activation of JNK by AICA-riboside 
A

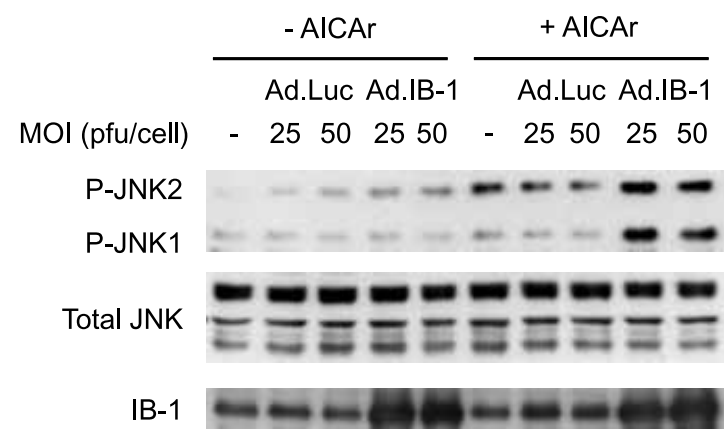

B

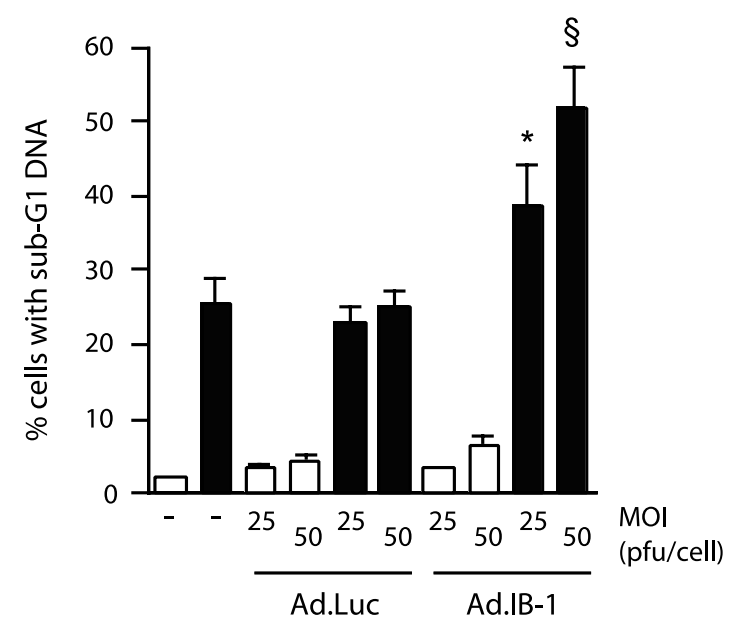

Figure 5 Expression of JIP-1/IB-1 augments AICA-riboside-induced JNK activation and apoptosis in MIN6 cells. (A) MIN6 cells were infected with adenovirus Ad.IB-1 expressing the scaffold protein JIP-1/IB-1 or Ad.Luc encoding luciferase, at the indicated multiplicities (MOI). After $24 \mathrm{~h}$ of viral expression, cells were cultured for a further $6 \mathrm{~h}$ in the absence or presence of $2 \mathrm{mM}$ AICA-riboside (AICAr). Phosphorylated JNK (P-JNK1/2), total JNK and IB-1 protein were then detected by immunoblotting using specific antibodies. Result shown is representative of three experiments. (B) Cells infected as in (A) were cultured for $30 \mathrm{~h}$ in the absence (white bars) or presence (black bars) of $2 \mathrm{mM}$ AICA-riboside, and analysed for induction of apoptosis. Data are expressed as per cent of cells with sub-G1 DNA content (as defined in Fig. 4B), and represent the means \pm S.E.M. of six experiments $\left({ }^{\star} P<0.05\right.$ and $\S P<0.01$ vs Ad.Luc MOI 25 and 50 respectively).

and that this in turn causes increased apoptosis. Taken together, these data indicate that JNK activation mediates AICA-riboside-induced caspase3 activation and apoptosis in MIN6 cells.

\section{Culture of MIN6 cells at low glucose resulted in a sequence of activations that is comparable with that observed with AICA-riboside}

Culture at low glucose $(0.6 \mathrm{mM})$ also induced apoptosis in MIN6 cells as it did in primary $\beta$-cells (Fig. 1A; Kefas et al. 2003). The kinetics of caspase-3 activation was comparable with that measured during AICA-riboside exposure, starting after $12 \mathrm{~h}$ and progressively increasing in the following $36 \mathrm{~h}$ up to 8-fold higher values than in control cells cultured at $25 \mathrm{mM}$ glucose (Fig. 1D).

The caspase-3 activation (Fig. 1D) was preceded by (i) an AMPK activation that started after $30 \mathrm{~min}$, became maximal at $4 \mathrm{~h}$, and persisted for at least $12 \mathrm{~h}$ (Fig. 6A), and (ii) a JNK activation that reached its maximum after 2-4 h (Fig. 6B). Culture of MIN6 cells at low glucose concentration is thus probably another condition in which apoptosis is induced through the successive activation of AMPK, JNK and caspase-3.

\section{Discussion}

Previous studies have shown that rat $\beta$-cells undergo apoptosis during prolonged exposure to low glucose levels (Hoorens et al. 1996) and to AICA-riboside (Kefas et al. 2003). It is now shown that this is also the case in insulinoma MIN6 cells. This cell line is known to exhibit an AMPK activation during culture at low glucose (Da Silva et al. 2000). We therefore used MIN6 cells to identify AMPK-regulated steps that can lead to apoptosis. AMPK was stimulated in two different conditions, namely culture at low glucose concentration, and addition of AICA-riboside.

Culture of MIN6 cells with AICA-riboside resulted in a time- and dose-dependent apoptosis, as documented by fluorescence microscopy and by FACS analysis of nuclear DNA. This effect was mediated by caspase activation as indicated by measurement of caspase- 3 activity and by the suppressive action of the general caspase inhibitor zVAD-fmk on oligonucleosomal DNA fragmentation.

Both the exposure to AICA-riboside and culture at low glucose concentration were found to first activate AMPK and JNK, and then caspase-3. When MIN6 cells were infected with adenovirus expressing the constitutively active $\alpha 1$-AMPK 
A

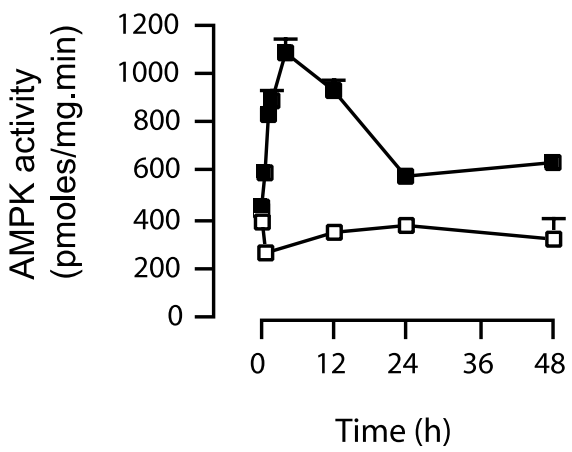

B

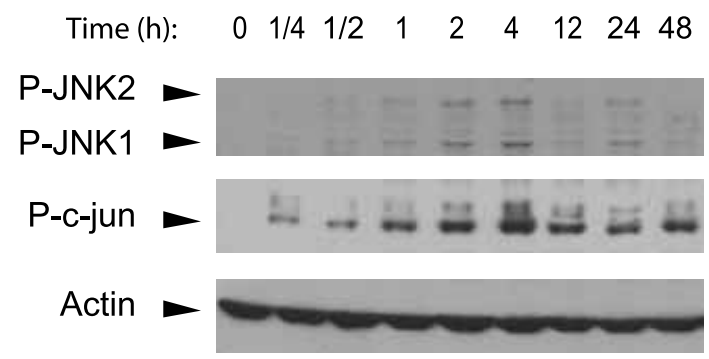

Figure 6 Sequential activation of AMPK and JNK by low glucose concentration in MIN6 cells. (A) MIN6 cells were maintained at $25 \mathrm{mM}$ glucose $(\square)$ or were shifted

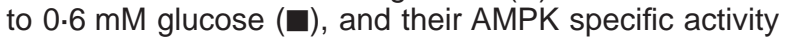
was determined after the indicated periods of time, as in Fig. 2A. The values shown are the means \pm S.E.M. of six experiments. (B) Phosphorylation of JNK (P-JNK1 and 2 ) and of C-Jun (P-C-jun) was assessed on the same time points as in (A), and as described for Fig. 2B. The results shown are representative of three experiments.

catalytic subunit, they underwent activation of endogenous JNK and increased DNA fragmentation, indicating that AMPK activation results in stimulation of JNK and apoptosis. In the presence of dicumarol, a known inhibitor of JNK activation, activation of caspase-3 and cellular DNA fragmentation by AICA-riboside were blunted. In addition, adenovirus expression of the scaffolding protein IB-1/JIP-1 in MIN6 cells augmented their JNK activation in the presence of AICA-riboside and led to an increased apoptosis. AICA-riboside was also found to induce JNK activation in primary $\beta$-cells. These results thus indicate that activation of AMPK can lead to JNK-mediated caspase-3 activation and apoptosis.

JNK activation has previously been shown to contribute to induction of apoptosis in pancreatic $\beta$-cells under adverse environmental conditions (Ammendrup et al. 2000). Our study suggests that AMPK is one factor transmitting extracellular signals leading to JNK activation, but it is so far unknown via which mechanism JNK could be activated by AMPK. The results obtained with IB-1-expressing adenovirus suggest that AMPK can stimulate JNK activation at the JNK-interacting scaffold protein JIP-1/IB-1, which is highly expressed in $\beta$-cells (Abderrahmani et al. 2001). It is not clear whether IB- $1 / \mathrm{JIP}-1$ is also required for AMPK-induced JNK activation and apoptosis; this could be addressed by assessing the effects of IB-1 downregulation. It is also not known which kinases mediate AMPK-induced JNK activation. That IB-1 expression increased the AMPK-induced JNK phosphorylation may indicate the involvement of upstream activators MKK7 and MLK-3, which are known to bind IB-1 and to phosphorylate JNK (Bonny et al. 2000). Similarly, the mechanisms whereby JNK induces apoptosis in our cell preparations are not known. Downstream apoptosis signalling by JNK in response to AMPK activation may involve phosphorylation of any of the immediate early gene regulating transcription factors Elk1, c-Jun and ATF2 in insulin-producing cells (Bonny et al. 2000). Phosphorylation of p53, upregulation of p53, transcriptional stimulation of the Bax gene, and upregulation of Fas ligand expression, have been implicated in other systems (Buschmann et al. 2001, Chen \& Lai 2001, Kobayashi \& Tsukamoto 2001, Mandal et al. 2001). JNK activation may generate pro- or anti-apoptotic signals depending on the cell type, the stimulus for and the kinetics of the activation. It has been noticed that a pro-apoptotic effect was associated with a sustained rather than with a transient JNK activation (Cross et al. 2000), a feature that would be compatible with our present observations.

This in vitro study suggests that AMPK activation is at least in part responsible for apoptosis of $\beta$-cells during prolonged exposure to low extracellular glucose levels or to activators of AMPK. While these conditions may not occur in vivo, it is conceivable that they can be mimicked in situations 
of inadequate intracellular glucose signalling such as glucokinase-deficient type 1 maturity-onset diabetes of the young (MODY). A possible role for AMPK activation in MODY has been suggested in view of its suppressive effect on the transcription factor hepatocyte nuclear factor-4 alpha (Leclerc et al. 2001). The present findings also suggest that potentially adverse effects on the viability of $\beta$-cells should be considered when assessing use of AICA-riboside as treatment for insulin resistance in type 2 diabetes (Winder \& Hardie 1999).

\section{Acknowledgements}

We thank G Waeber and J Haefliger (Lausanne), D Carling (London), P Vandenabeele (Ghent), and D Meisse, Y Feng, G Stangé, Y Heremans and N Caluwé (Brussels) for their help. $\mathrm{H} \mathrm{H}$ is a recipient of a postdoctoral research fellowship from the Belgian Fonds voor Wetenschappelijk Onderzoek. This work was supported by grants from the Belgian Fonds voor Wetenschappelijk Onderzoek G.0376.97 and services of the Belgian Prime Minister (Interuniversity Attraction Pole P5/17).

\section{References}

Abderrahmani A, Steinmann M, Plaisance V, Niederhauser G, Haefliger JA, Mooser V, Bonny C, Nicod P \& Waeber G 2001 The transcriptional repressor REST determines the cell-specific expression of the human MAPK8IP1 gene encoding IB1 (JIP-1). Molecular and Cellular Biology 21 7256-7267.

Ammendrup A, Maillard A, Nielsen K, Aabenhus Andersen N, Serup P, Dragsbaek Madsen O, Mandrup-Poulsen T \& Bonny C 2000 The c-Jun amino-terminal kinase pathway is preferentially activated by interleukin-1 and controls apoptosis in differentiating pancreatic beta-cells. Diabetes 49 1468-1476.

Bonny C, Oberson A, Steinmann M, Schorderet DF, Nicod P \& Waeber G 2000 IB1 reduces cytokine induced apoptosis in insulin-secreting cells. Fournal of Biological Chemistry 275 16466-16472

Buschmann T, Potapova O, Bar-Shira A, Ivanov VN, Fuchs SY, Henderson S, Fried VA, Minamoto T, Alarcon-Vargas D, Pincus MR et al. 2001 Jun NH2-terminal kinase phosphorylation of p53 on Thr-81 is important for p53 stabilization and transcriptional activities in response to stress. Molecular and Cellular Biology 21 2743-2754.

Chen Y \& Lai MZ 2001 c-Jun NH2-terminal kinase activation leads to a FADD-dependent but Fas ligand-independent cell death in Jurkat T cells. Fournal of Biological Chemistry 276 8350-8357.

Corton JM, Gillespie JG \& Hardie DG 1994 Role of the AMP-activated protein kinase in the cellular stress response. Current Biology 4 315-324.

Corton JM, Gillespie JG, Hawley SA \& Hardie DG 1995 5-Aminoimidazole-4-carboxamide ribonucleoside: a specific method for activating AMP-activated protein kinase in intact cells? European Fournal of Biochemistry 229 558-565.
Cross TG, Scheel-Toellner D, Henriquez NV, Deacon E, Samon M \& Lord JM 2000 Serine/threonine kinases and apoptosis. Experimental Cell Research $25634-41$.

da Silva Xavier G, Leclerc I, Salt IP, Doiron B, Hardie DG, Kahn A \& Rutter GA 2000 Role of AMP-activated protein kinase in the regulation of glucose islet beta cell gene expression. PNAS $\mathbf{9 7}$ 4023-4028.

Davies SP, Hawley SA, Woods A, Carling D, Haystead TAJ \& Hardie DG 1994 Purification of the AMP-activated protein kinase on ATP-gamma-sepharose and analysis of its subunit structure. European Fournal of Biochemistry 223 351-357.

Hardie DG \& Carling D 1997 The AMP-activated protein kinase. Fuel gauge of the mammalian cell. European Fournal of Biochemistry 246 259-273.

Hardie DG, Carling D \& Carlson M 1998 The AMP-activated/ SNF1 protein kinase subfamily: metabolic sensors of the eukaryotic cell. Annual Review of Biochemistry 67 821-855.

Heimberg H, Bouwens L, Heremans Y, Van de Casteele M, Lefebvre V \& Pipeleers D 2000 Adult human pancreatic duct and islet cells exhibit similarities in expression and differences in phosphorylation and complex formation of the homeodomain protein Ipf-1. Diabetes 49 571-579.

Hoorens A, Van de Casteele M, Kloppel G \& Pipeleers D 1996 Glucose promotes survival of rat pancreatic beta cells by activating synthesis of proteins which suppress a constitutive apoptotic program. Foumal of Clinical Investigation 98 1568-1574.

Kefas B, Heimberg H, Vaulont S, Meisse D, Hue L, Pipeleers D \& Van de Casteele M 2003 AICA-riboside induces apoptosis of pancreatic beta cells through stimulation of AMP-activated protein kinase. Diabetologia (In Press).

Kobayashi K \& Tsukamoto I 2001 Prolonged Jun N-terminal kinase (JNK) activation and the upregulation of p53 and p21(WAF1/CIP1) preceded apoptosis in hepatocytes after partial hepatectomy and cisplatin. Biochimica et Biophysica Acta 1537 79-88.

Krause D, Lyons A, Fennelly C \& O'Connor R 2001 Transient activation of Jun N-terminal kinases and protection from apoptosis by the insulin-like growth factor I receptor can be suppressed by dicumarol. Fournal of Biological Chemistry 276 19244-19252.

Leclerc I, Lenzner C, Gourdon L, Vaulont S, Kahn A \& Viollet B 2001 Hepatocyte nuclear factor-4 alpha involved in type 1 maturity-onset diabetes of the young is a novel target of AMP-activated protein kinase. Diabetes 50 1515-1521.

Mandal M, Olson DJ, Sharma T, Vadlamudi RK \& Kumar R 2001 Butyric acid induces apoptosis by up-regulating Bax expression via stimulation of the c-Jun N-terminal kinase/activation protein-1 pathway in human colon cancer cells. Gastroenterology $\mathbf{1 2 0}$ $71-78$.

Marsin AS, Bertrand L, Rider MH, Deprez J, Beauloye C, Vincent MF, Van den Berghe G, Carling D \& Hue L 2000 Phosphorylation and activation of heart PFK-2 by AMPK has a role in the stimulation of glycolysis during ischaemia. Current Biology 10 1247-1255.

Miller SA, Dykes DD \& Polesky HF 1988 A simple salting out procedure for extracting DNA from human nucleated cells. Nucleic Acids Research $\mathbf{1 6} 1215$.

Moore F, Weekes J \& Hardie DG 1991 Evidence that AMP triggers phosphorylation as well as direct allosteric activation of rat liver AMP-activated protein kinase. A sensitive mechanism to protect the cell against ATP depletion. European Fournal of Biochemistry 199 691-697.

Musi N, Fujii N, Hirshman MF, Ekberg I, Froberg S, Ljungqvist O, Thorell A \& Goodyear LJ 2001 AMP-activated protein kinase (AMPK) is activated in muscle of subjects with type 2 diabetes during exercise. Diabetes 50 921-927.

Nicoletti I, Migliorati Gi, Pagliacci MC, Grignani F \& Riccardi Ci 1991 A rapid and simple method for measuring thymocyte 
apoptosis by propidium iodide staining and flow cytometry. Fournal of Immunological Methods 139 271-279.

Sabina RL, Patterson D \& Holmes EW 1985 5-Amino-4-imidazole carboxamide riboside (Z-riboside) metabolism in eukaryotic cells. Journal of Biological Chemistry 260 6107-6114.

Salt IP, Johnson G, Ashcroft SJH \& Hardie DG 1998

AMP-activated protein kinase is activated by low glucose in cell lines derived from pancreatic beta cells, and may regulate insulin release. Biochemical Fournal 335 533-539.

Sullivan JE, Brocklehurst KJ, Marley AE, Carey F, Carling D \& Beri RK 1994 Inhibition of lipolysis and lipogenesis in isolated rat hepatocytes with AICAR, a cell permeable activator of AMP-activated protein kinase. FEBS Letters 353 33-36.

Tawadros T, Formenton A, Dudler J, Thompson N, Nicod P, Leisinger HJ, Waeber G, Haefliger JA 2002 The scaffold protein IB1/JIP-1 controls the activation of JNK in rat stressed urothelium. Fournal of Cell Science 115 385-393.
Van de Casteele M, Kefas BA, Ling Z, Heimberg H \& Pipeleers DG 2002 Specific expression of Bax-omega in pancreatic beta-cells is down-regulated by cytokines before the onset of apoptosis. Endocrinology 143 320-326.

Winder WW \& Hardie DG 1999 AMP-activated protein kinase a metabolic master switch: possible roles in type 2 diabetes. American Fournal of Physiology, Endocrinology and Metabolism 277 E1-E10.

Woods A, Azzout-Marniche D, Foretz M, Stein S, Lemarchand P, Ferré P, Foufelle F \& Carling D 2000 Characterization of the role of AMP-activated protein kinase in the regulation of glucoseactivated gene expression using constitutively active and dominant negative forms of the kinase. Molecular and Cellular Biology 20 6704-6711.

Received in final form 1 December 2002 Accepted 14 December 2002 